\title{
An incidental case of asymptomatic intracranial foreign body on CT
}

\author{
Mehmet Deveer, ${ }^{1}$ Fatmagul Imamoglu, ${ }^{2}$ Cetin Imamoglu, ${ }^{2}$ Sarper 0 Okten $^{3}$
}

1Department of Radiology, Faculty of Medicine, Mugla Sitki Kocman University, Mugla, Turkey

${ }^{2}$ Department of Radiology, Yunus Emre State Hospital Eskisehir, Turkey ${ }^{3}$ Department of Radiology, Türkiye Yüksek Ihtisas Hospital, Ankara, Turkey

\section{Correspondence to} Dr Mehmet Deveer, deveer3@hotmail.com
To cite: Deveer $\mathrm{M}$, Imamoglu F, Imamoglu C, et al. BMJ Case Rep Published online: [please include Day Month Year] doi:10.1136/bcr-2013010230

\section{DESCRIPTION}

Although not common, cases of foreign bodies are important and interesting. Foreign bodies enter the body by trauma or iatrogenic injuries. Because of the thin nature of the bony orbital skeleton, intracranial pencil injuries are often transorbital. ${ }^{1}$ This article was to present a case of intracranial foreign body in a CT obtained from a patient with presyncope after over-exertion.

A non-contrast and contrast-enhancing CT was obtained from a 43-year-old man, who suffered only once 3 days earlier from a presyncope, otherwise with healthy work-life and sport-life.

A $56 \mathrm{~mm}$ long foreign body with regular borders and sharp tip, entering the right frontal lobe adjacent to the putamen with a defect on the right sphenoid bone, reaching to corona radiata with a hyperdense surrounding and free air was seen on the axial and reformated cross-sectional CT images (figures 1-3).

After the CT scan, the patient was questioned again and we were informed that 14 years earlier the patient fell and a pen penetrated his right orbita. The right globe was tomographycally normal. No areas of intracranial haematoma or encephalomalacia were seen. The asymptomatic nature of the foreign body may be due to the good tolerance of plastic objects in the body, not injuring any vascular structures and its localisation on the right lobe (figure 4).
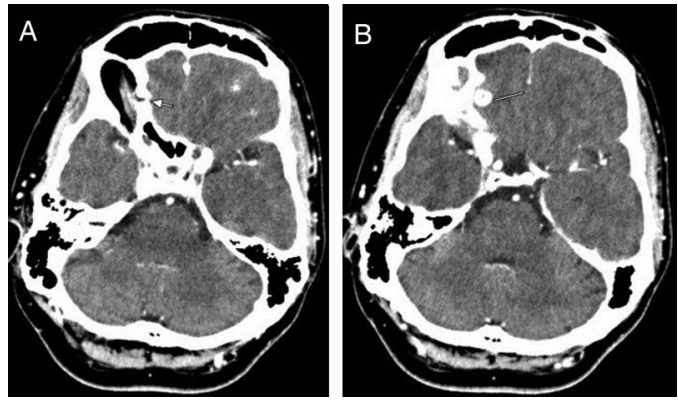

Figure 1 A defect of the sphenoid bone $(A)$ and a foreign body $(B)$ on the neighbouring brain parenchyma is seen on the contrast-enhancing CT cross sections.

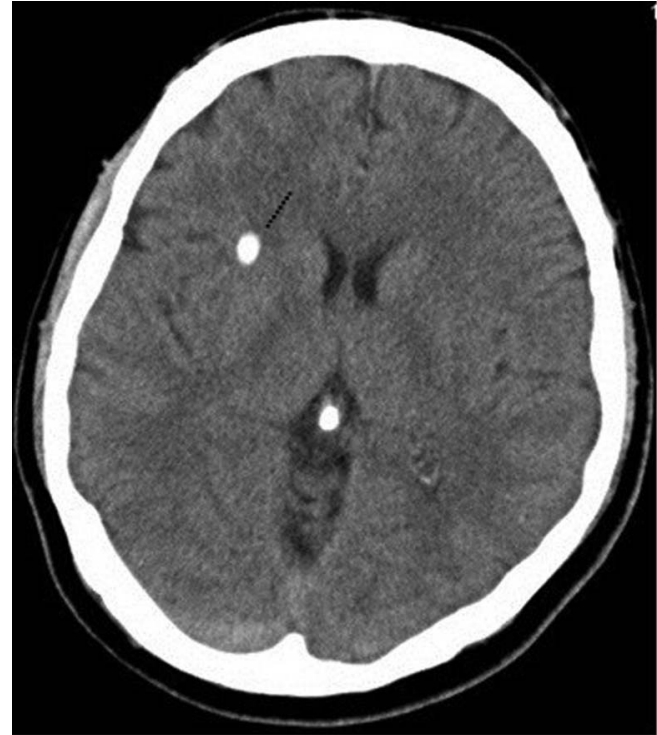

Figure 2 A foreign body is seen at the level of the basal ganglia on non-contrast CT.
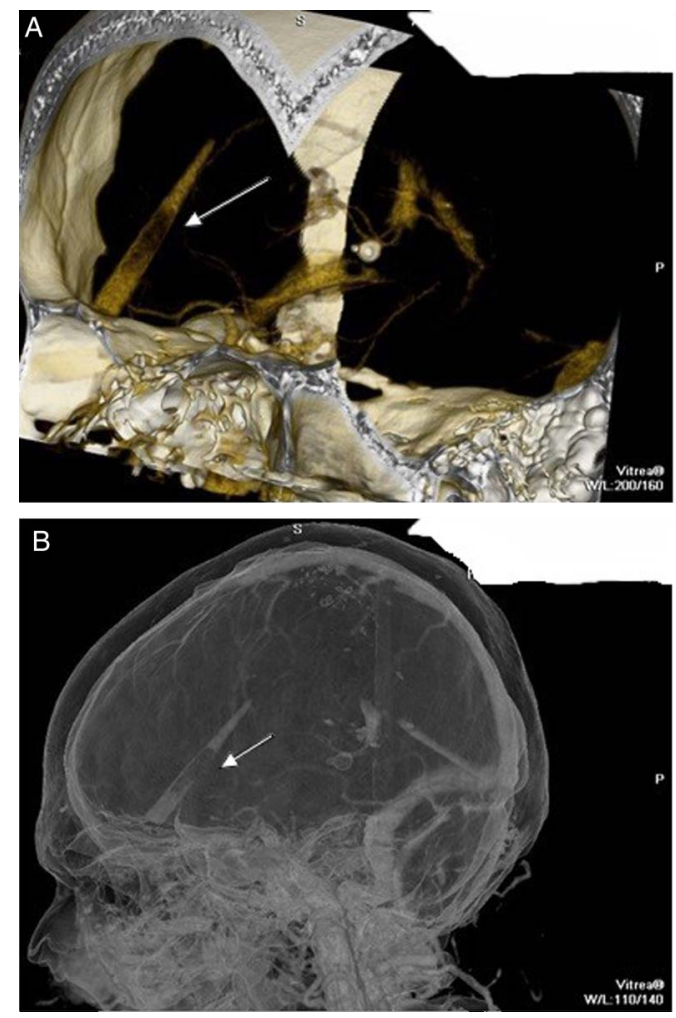

Figure 3 The image of the foreign body on the volume rendering $(\mathrm{A})$ and multiplanar refomatted $\mathrm{CT}(\mathrm{B})$. 


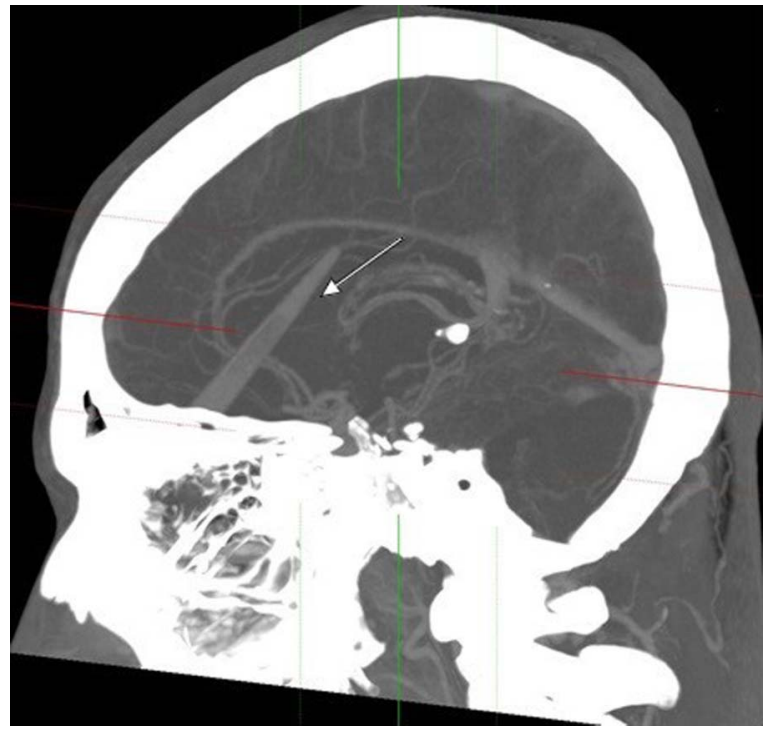

Figure 4 According to the reformatted multiplanar refomatted CT images, although the foreign body was close to vascular structures no vascular injuries were caused.

\section{Learning point}

Because of the thin nature of the bony orbital skeleton, intracranial pencil injuries are often transorbital. Especially in penetrating orbital traumas, a brain $\mathrm{CT}$ should be obtained for the evaluation of intracranial foreign objects even if the patients appears asymptomatic.

Acknowledgements This case was presented as a poster at the Turkish National Congress of Radiology.

Competing interests None.

Patient consent Obtained.

Provenance and peer review Not commissioned; externally peer reviewed.

\section{REFERENCE}

1 Matsumoto S, Hasuo K, Mizushima A, et al. Intracranial penetrating injuries via the optic canal. Am J Neuroradiol 1998;19:1163-5.

Copyright 2013 BMJ Publishing Group. All rights reserved. For permission to reuse any of this content visit http://group.bmj.com/group/rights-licensing/permissions.

BMJ Case Report Fellows may re-use this article for personal use and teaching without any further permission.

Become a Fellow of BMJ Case Reports today and you can:

- Submit as many cases as you like

- Enjoy fast sympathetic peer review and rapid publication of accepted articles

- Access all the published articles

- Re-use any of the published material for personal use and teaching without further permission

For information on Institutional Fellowships contact consortiasales@bmjgroup.com

Visit casereports.bmj.com for more articles like this and to become a Fellow 